\title{
The Spatial Analysis in Tuna Habitat Related to The Ocean Variability in The Indian Ocean
}

\author{
Abu Bakar Sambah \\ Department of Fisheries Resources Utilization \\ Fisheries and Marine Science Faculty, \\ Brawijaya University, Malang, Indonesia \\ Marine Resources Exploration and Management \\ Research Group (MEXMA) \\ Corresponding Email: absambah@yahoo.com \\ Feni Iranawati \\ Department of Marine Science \\ Fisheries and Marine Science Faculty, \\ Brawijaya University, Malang, Indonesia \\ Marine Resources Exploration and Management \\ Research Group (MEXMA) \\ Syarifah H Julindasari \\ Department of Marine Science \\ Fisheries and Marine Science Faculty, \\ Brawijaya University, Malang, Indonesia \\ Marine Resources Exploration and Management \\ Research Group (MEXMA) \\ Dian Pranoto \\ Department of Fisheries Resources Utilization \\ Fisheries and Marine Science Faculty, \\ Brawijaya University \\ Malang, Indonesia \\ Ledhyane Ika Harlyan \\ Department of Fisheries Resources Utilization \\ Fisheries and Marine Science Faculty, \\ Brawijaya University, Malang, Indonesia \\ Marine Resources Exploration and Management \\ Research Group (MEXMA) \\ Ahmad Fauzan Ghafiky \\ Department of Marine Science \\ Fisheries and Marine Science Faculty, \\ Brawijaya University, Malang, Indonesia
}

\begin{abstract}
One of marine fisheries resources utilization problems is the difficulty of determining the exact fishing ground, including for big pelagic fish. The use of fishing ground map by local fisherman has not shown significant catches in fishing operation. The research aims were to inventory catch and fishing ground of tuna collected directly from Cilacap fisherman, to know the correlation between tuna catch composition and their fishing ground distribution, and to analyze the spatial correlation
\end{abstract}

between fishing ground and oceanography variability in the Indian Ocean. The analysis applied to both tuna fish and baby tuna for the species of big eye tuna. The research applied spatial and temporal analysis of Aqua-MODIS images in the year of 2006 until 2015, and the analysis of big eye tuna catch effort for 2015. The research showed that based on fishing ground and catch, big eye tuna catch was $9.724 \mathrm{~kg}$ on August in the coordinate of $108.67^{\circ} \mathrm{E}$ longitude and $09.50^{\circ} \mathrm{S}$ latitude, big eye tuna (big and 
baby) was $17.092 \mathrm{~kg}$ on September in the coordinate of $108.83^{\circ} \mathrm{E}$ and $08.50^{\circ} \mathrm{S}$, and big eye baby tuna was $7.896 \mathrm{~kg}$ on January in the coordinate of $107.00^{\circ} \mathrm{E}$ and $\mathbf{0 8 . 0 0}^{\circ} \mathrm{S}$. Bigeye tuna is more dominant caught than big eye baby tuna in Southern Java between $105.00^{\circ}$ to $110.00^{\circ} \mathrm{E}$ longitude and $08.00^{\circ}$ to $10.00^{\circ} \mathrm{S}$ latitude, and slightly in Southwestern of Java. Based on the distribution of big eye tuna fishing ground in the Indian Ocean described that big eye tuna were caught in the range of SST, chlorophyll-a, and SSHA of $25-30^{\circ} \mathrm{C}, 0.10-0.71 \mathrm{mg} / \mathrm{m3}$ and $-0.14-$ $0.16 \mathrm{~m}$. The accuracy assessment of tuna fishing ground during 2015 by local fisherman associated with the prediction of potential fishing ground showed $78,82 \%$ of accuracy.

Keywords-Tuna; fishing ground; oceanography parameters; Indian Ocean.

\section{INTRODUCTION}

In general, tuna distribute widely in three oceans, Indian, Pacific, and Atlantic (O.K. Sumadhiharga, 2009). In Indonesia, most of this species was caught in the south waters of Java, southwest of

South Sumatra, Bali, Nusa Tenggara, Banda Sea and the Maluku Sea (S. Riswanto, 2012). Indian Ocean has dominated by four tuna species, albakor (Thunnus alalunga), big eye (Thunnus obesus), yellowfin tuna (Thunnus albacares) and skipjack tuna (Katsuwonus pelamis). Among the four species, big eye tuna is a highest economic value. About $18 \%$ of big eye tuna production in the world was supplied by the Indian Ocean or the third largest supplier in the world market (Lee, 2015). Big eye tuna is the target of a long liner from Japan, China, Taiwan and Indonesia. In the eastern part of the Indian Ocean, especially in the south waters of Java, big eye tuna was the main commercial targets in fishing operation (M.L. Syamsuddin, 2013).

In some areas, the exploitation status of big eye tuna reported in fully exploited, so that fishing activity can be a threat to big eye tuna. In response to such cases, the strategic management for tuna fishing efforts should be made in order to utilize the tuna resources sustainable. The fishing effort of tuna species needs a lot of consideration including the information of tuna habitat. Identification of tuna habitat can be a reference in tuna management policies in the Indian Ocean. Several models have been developed to examine the relationship between the distribution of tuna and their habitat.

The use of linear regression models, linear additive models, multiple linear regression model, logistic regression models, habitat suitability index models and quantile regression model have been applied for tuna habitat study. Some studies include a combination of these modeling systems to develop a spatial analysis for habitat mapping (L. Song, 2010). Moreover, the use of oceanographic data from remote sensing approach combine with the catch effort survey data is one of the methods in determining the habitat of tuna species.

The potential fishing ground for tuna species can be map using the analysis of oceanographic parameters. The use of common fishing ground map that published and distributed by
Indonesia government sometimes face the difficulties in ensuring the exact location of fish habitat because the limitation of data validation, including the feedback from tuna long liner. This study tried to analyze the relationship between tuna habitat and ocean variability for tuna habitat mapping, and also tried to validate the fishing ground map of tuna with the fishing ground point collected using participatory mapping.

\section{METHOD}

\section{A. Dataset}

The oceanographic parameters, Sea Surface Temperature/SST and Chlorophyll-a/Chl-a, monthly data in 11 $\mu$ daylight from Aqua Modis from ocean color web (http://oceancolor.gsfc.nasa.gov/) were applied. Sea Surface Height Anomaly/SSHA in L-4 from Jason-2 data set also applied (http://marine.copernicus.au/). Data acquisition for oceanographic parameter was in the year of 2006 until 2015. Moreover, tuna catch effort data collected from Cilacap Fishing Port and the fishing ground point form local fisherman were used for the validation.

\section{B. Data Analysis}

Ocean variability data was analyzed based on the anomalies value. The analysis continued by trend analysis to describe the pattern of Indian Ocean variability in 10 years. The trend will be described in regression equation. SST analysis was applied to know the area of upwelling. Analysis of Chl-a distribution was used in order to determine areas with high primary productivity. Moreover, the analysis of SSHA was used to estimate the effect of sea level high in different tuna catch per month. For describing tuna catch data, the calculation of Catch per Unit Effort/CpUE was done using:

$$
\operatorname{CpUE}_{i}=\operatorname{Catch}_{i} /_{\text {Effort }}
$$

Where;

$C p U E i$ is Catch per unit effort (trip) in year-i (ton/unit)

Catchi is tuna catches in year-i (ton)

Efforti is tuna fishing operation in year-i (unit)

The correlation analysis was applied to describe the relationship of each oceanographic parameter and the relationship between oceanographic parameters and tuna catch. The correlation analysis was calculated using :

$$
r=\sum \frac{x y}{\sqrt{\sum x y^{2} \times \sum y^{2}}}
$$

The correlation coefficient was between $-1 \geq \mathrm{r} \leq 1$, where negative correlation was in the range of -1 to 0 , while the positive was 0 to 1 (G.A. Latumeten, 2013). Validation of potential tuna fishing ground was calculated using overall accuracy formula.

\section{FINDING AND DISCUSSION}

\section{A. Ocean Variability}

The average of SST over 10 years in the Indian Ocean was $27.95^{\circ} \mathrm{C}$ where the lowest temperature occurred in November 
$2006\left(27.33^{\circ} \mathrm{C}\right)$ and the highest was in September 2010 $\left(30.05^{\circ} \mathrm{C}\right)$. The trend of SST anomalies in 10 years tends to increase. This is due to the effects of global warming that indicated by increasing of SST in $0.1^{\circ} \mathrm{C} /$ year (S.I. Sachoemar, 2000). In addition, the increasing of SST was also influenced by IOD and ENSO (M. N. Habibi, 2014). Generally, SST will decrease along with the decreasing of latitude. However, the low value of SST was also found in waters close to the Java Island. This low temperature anomaly can be indicative of the occurrence of upwelling (P. Kemili, 2012).

Upwelling that occurs in coastal area of Java is due to Ekman transport as a result of southeast winds and hindered by the south side of Java Island (S.I. Sachoemar, 2000).

The concentration of chlorophyll-a in the Indian Ocean was relatively homogeneous. This concentration was highly diverse and tends to increase towards the north part (close to the southern part of Java Island). The high concentration of chlorophyll-a near the coastal area of Java Island was caused by seasonal upwelling process (R. Dwi Susanto, 2001).

The SSHA described that sea level height tend to increase in the year of 2006 until 2015. SSHA reached the lowest elevation in November $2006(-0.12 \mathrm{~m})$, and the highest in December $2010(0.162 \mathrm{~m})$. Spatial and temporal variation of oceanographic parameters described in Figure 1.

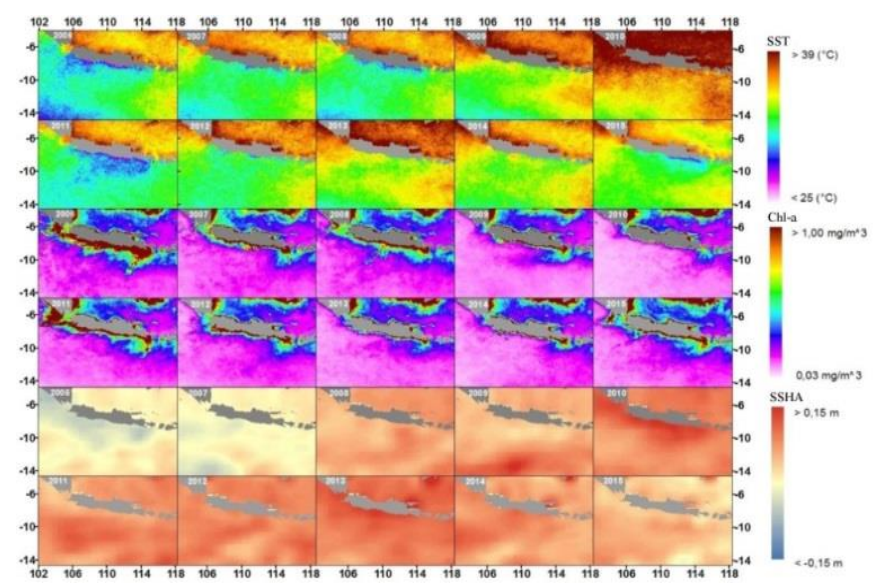

Fig. 1. Ocean variability described the spatial distribution of SST, Chl-a, and SSHA in Indian Ocean

The correlation of all oceanographic parameters was analyze to know the relationship between parameters. Pearson correlation (Table 1) described that SST has a very strong correlation negatively with chlorophyll-a $(\mathrm{r}=-0.706)$. Both parameters were significant correlations $(0.00<0.05)$. The inverse correlation of both parameters due to the SST indicates the intensity of light received by phytoplankton as a provider of chlorophyll-a. Reference (J. W. Nybakken, 1997). stated that high-intensity light will damage chlorophyll-a, and will interfere with the process of photosynthesis. Indirect relationships also happen seasonally in which the SST with low value indicates water surface masses that carry nutrients, ensuring primary productivity by increasing the concentration of chlorophyll-a in water (S. Nurdin, 2013).
Chlorophyll-a has a negative relationship to SSHA ( $\mathrm{r}=$ 0.416). Both parameters were significant correlations $(0.00<0.05)$. This correlation was related to the occurrence of upwelling. Reference (C. Wilson, 2001) states that the SSHA plays as an indicator of thermocline depth. The depth of thermocline indicated the occurrence of upwelling that brings nutrients from the bottom to the surface. SST has a very weak relationship and directly proportional to the SSHA $(r=0.103)$.

The correlation of both parameters were not significant $(0.263>0,05)$. This weak positive relationship was due to the influence of the season. Reference (P. D. Jones, 1999) suggests that the relationship between the SST and SSHA was a smallscale relationship or seasonal scale. During summer, the correlations tend to be weak, and tend to strengthen during winter.

TABLE I. CORRELATION VALUE OF OCEAN PARAMETERS

\begin{tabular}{|c|c|c|c|c|}
\hline & & SST & CHL-A & SSHA \\
\hline \multirow[t]{2}{*}{ SST } & CORRELATION & 1 & -0.70 & 0.10 \\
\hline & SIG. & & 0.00 & 1.26 \\
\hline \multirow[t]{2}{*}{ CHL-A } & CORRELATION & -0.70 & 1 & -0.41 \\
\hline & SIG. & 0.00 & & 0.00 \\
\hline \multirow[t]{2}{*}{ SSHA } & CORRELATION & 0.10 & -0.41 & 1 \\
\hline & SIG. & 0.26 & 0.00 & \\
\hline
\end{tabular}

SST anomalies in 2006 are likely to be decrease, and tend to increase in the beginning of 2007. In the other hand, Chl-a anomalies increased in July 2006 and reached its peak in November 2006, and decreased in April 2007. Moreover, the anomaly of $\mathrm{SSH}$ tend to decrease in the same period. The anomalies of the parameters in 2006-2007 was refers to the phenomenon of inter-annual in Indian Ocean, as reference (D. Pramudyo, 2011) stated. In this period, it described a positive of Indian Ocean Dipole (IOD) which indicated by the decrease of SST in the eastern part of Indian Ocean. IOD was associated with very strong value of Chl-a in upwelling zona along southern coastal area of Sumatera and Java.

Other phenomenon occurred in Indian Ocean during the period of 2006-2015 was El-Nino and La-Nina. During El-Nino event, SST and SSH anomalies tend to increase, while the concentration of Chl-a decreased. In addition, during the phenomenon of La-Nina, SST anomalies tend to decrease, while Chl-a increased and indicated upwelling events (see Figure 2). Habibie and Nurainis (2014) stated that the Indian Ocean mostly affected by IOD than ENSO. 


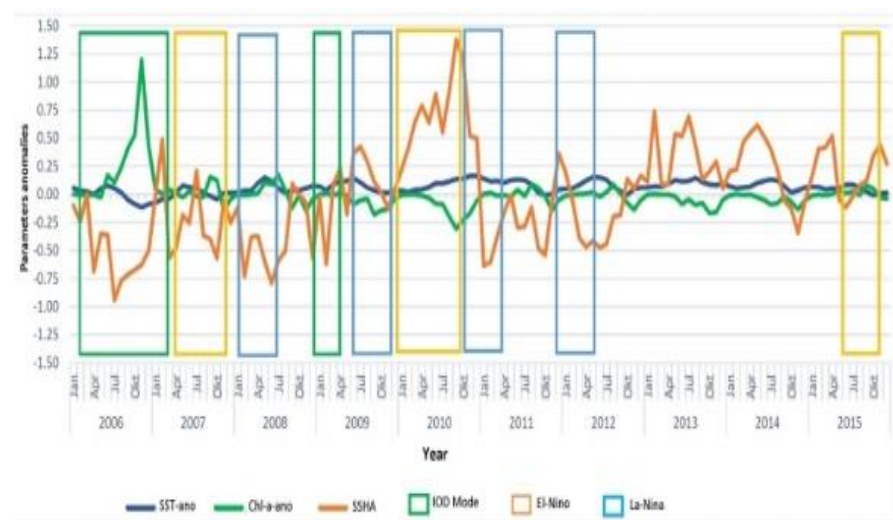

Fig. 2. Ocean variability of each oceanographic parameters related to the IOD, El-Nino, and La-Nina events

\section{B. Catch per Unit Effort (CpUE)}

CpUE was used as a parameter in determining fishing gear productivity, so that this applied as one of the indicators in sustainable fisheries management. CpUE was calculated based on tuna catch from the different fishing gear; drift gillnet, drift longline, and tuna longline recorded in Cilacap fishing port.

Fishing gear has an ability to catch more than one fish species, not only fish target but also non target species or by catch species. Fishing gear standardization was needed to analyze the capability of fishing gear. Based on the CpUE calculation in the year of 2010-2015, the highest average catch of tuna was from tuna longline (0.577 ton/unit), followed by drift longline (0.257 ton/unit), and drift gillnet (0.057 ton/unit). It can be conclude that tuna longline was a standard fishing gear for tuna catch.

Relative Fishing Power (RFP) was needed to calculate conversion index of fishing gear. It can be obtained from the division of CpUE for each fishing gear and the CpUE of standard fishing gear (tuna longline). RFP calculation shows in Table 2, while the effort value and standard effort of tuna fishing gear describes in Table 3. In order to determine catch effort standard for tuna longline, catch effort was multiplied by RFPs $=1$. For other fishing gear was multiplied by RFPi for each year.

TABLE II.

CPUE VALUE AND RFP OF TUNA FISHING GEAR

\begin{tabular}{|c|c|c|c|c|c|c|}
\hline \multirow{2}{*}{ YEAR } & \multicolumn{2}{|c|}{ DRIFT GILLNET } & \multicolumn{2}{c|}{ DRIFT LONGLINE } & \multicolumn{2}{c|}{ TUNA LONGLINE } \\
\cline { 2 - 7 } & $\begin{array}{c}\text { CPUE } \\
\text { (TON/UNIT) }\end{array}$ & RFPI & $\begin{array}{c}\text { CPUE } \\
\text { (TON/UNIT) }\end{array}$ & RFPI & $\begin{array}{c}\text { CPUE } \\
\text { (TON/UNIT) }\end{array}$ & RFPS \\
\hline 2010 & 0.278 & 0.94 & 0.021 & 0.07 & 0.295 & 1 \\
\hline 2011 & 0.196 & 0.78 & 0.057 & 0.23 & 0.249 & 1 \\
\hline 2012 & 0.202 & 0.77 & 0.010 & 0.04 & 0.262 & 1 \\
\hline 2013 & 0.321 & 0.82 & 0.097 & 0.25 & 0.391 & 1 \\
\hline 2014 & 0.248 & 0.92 & 0.134 & 0.50 & 0.269 & 1 \\
\hline 2015 & 0.300 & 0.15 & 0.024 & 0.01 & 1.998 & 1 \\
\hline & 0.257 & & 0.057 & & 0.577 & \\
\hline
\end{tabular}

Source: Analysis of fisheries statistic data 2010-2015
TABLE III. EFFORT VALUE AND EFFORT STANDART OF TUNA FISHING GEAR

\begin{tabular}{|c|c|c|c|c|c|c|}
\hline \multirow{3}{*}{ YEAR } & \multicolumn{2}{|c|}{ DRIFT GILLNET } & \multicolumn{2}{c|}{ DRIFT LONGLINE } & \multicolumn{2}{c|}{ TUNA LONGLINE } \\
\cline { 2 - 7 } & $\begin{array}{c}\text { EFFOR } \\
\text { T } \\
\text { (UNIT) }\end{array}$ & $\begin{array}{c}\text { EFFOR } \\
\text { T } \\
\text { STAND } \\
\text { ARD } \\
\text { (UNIT) }\end{array}$ & $\begin{array}{c}\text { EFFORT } \\
\text { (UNIT) }\end{array}$ & $\begin{array}{c}\text { EFFOR } \\
\text { T } \\
\text { STAND } \\
\text { ARD } \\
\text { (UNIT) }\end{array}$ & $\begin{array}{c}\text { EFFOR } \\
\text { T } \\
\text { (UNIT) }\end{array}$ & $\begin{array}{c}\text { EFFOR } \\
\text { T } \\
\text { STAND } \\
\text { ARD } \\
\text { (UNIT) }\end{array}$ \\
\hline 2010 & 1362 & 1282 & 7 & 1 & 1271 & 1271 \\
\hline 2011 & 1463 & 1152 & 61 & 14 & 1679 & 1679 \\
\hline 2012 & 1779 & 1370 & 17 & 1 & 882 & 882 \\
\hline 2013 & 2296 & 1886 & 49 & 12 & 255 & 255 \\
\hline 2014 & 1385 & 1277 & 100 & 50 & 121 & 121 \\
\hline 2015 & 924 & 139 & 76 & 1 & 154 & 154 \\
\hline
\end{tabular}

Source: Analysis of fisheries statistic data 2010-2015

Based on the fishing gear standardization, it describes that the trend of catch effort tend to decrease due to long distance of fishing ground and uncertain of tuna fishing ground.

\section{Fishing Ground}

Fishing ground points collected from participatory mapping consist of 865 points. This area was bounded from $93.67^{\circ} \mathrm{E}$ and $07.33^{\circ} \mathrm{S}$ in the west part of study area until $110.50^{\circ} \mathrm{E}$ and $09.50^{\circ} \mathrm{S}$ in the east part, as well as $101.50^{\circ} \mathrm{E}$ and $12.20^{\circ} \mathrm{S}$ in the southern part. Fishing ground distribution illustrated that commonly tuna habitat spread in the area of constant concentration of Chl-a and SST not too low. The high tolerance of SSHA indicated in the fishing ground in all gradient of color (Figure 3). The highest catch of tuna was found in the low SSHA. Season plays an important role in characterizing the condition of Indian Ocean, especially for the distribution of primary productivity as one of the indicators in tuna suitability habitat mapping.

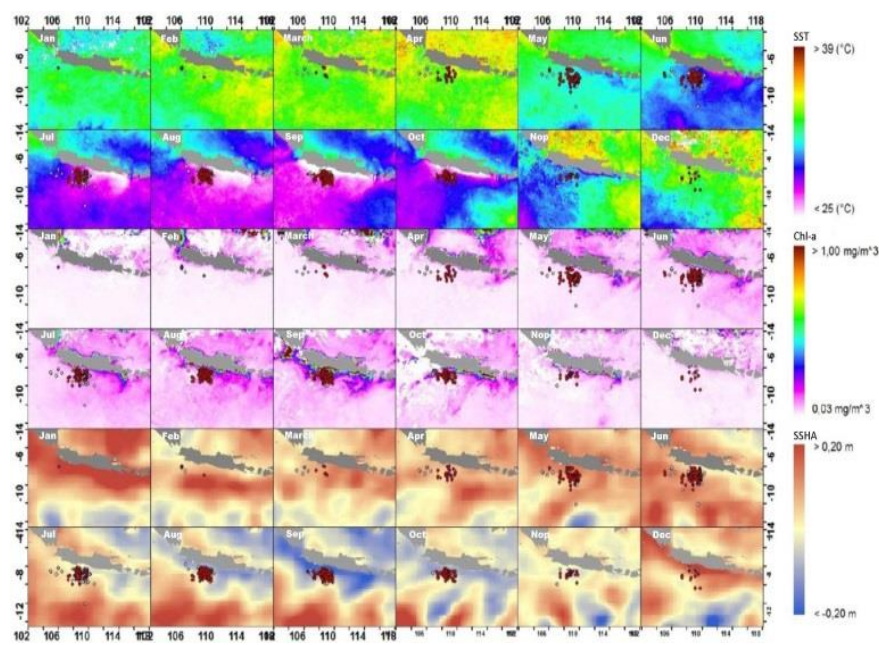

Red point illustrated tuna fishing ground

Fig. 3. Ocean variability related to tuna fishing ground point of local fishermen in the Cilacap fishing port (Source: fishing trip and ocean color data analysis, 2015)

The peak of tuna catch was in east monsoon (on June, July, and August). In this season, SST reached its low value (less than $25^{\circ} \mathrm{C}$ ). The decreasing of SST followed by the increasing of Chl-a, also SSHA level tend to decrease below -0.2 meter. On the other hand, during west monsoon, SST tent to increase and followed by the decreasing of Chl-a. The decreasing of 
SSHA generally found in the coastal area of Java Island due to Ekman transport and low level of thermocline layer ( $\mathrm{J}$. Lumban-Gao, 2015). The upwelling events started on June and reached its peak on September, where gave a positive impact to the catch of tuna (S.I. Sachoemar, 2000). The high level of SSHA was mostly affected by southern equatorial current, which moved from the west part of Sumatera Island to the southern part of Java Island as a Java coastal current. The existence of this current will increase SSHA level in the eastern part of Java Island (M. Purba, 1992).

The highest catch of bigeye tuna species in 2015 was $17.092 \mathrm{~kg}$ on September. It found in the coordinate of $108.83^{\circ}$ $\mathrm{E}$ and $08.50^{\circ} \mathrm{S}$. Generally, tuna was caught in the Indian Ocean between the coordinate of $105.00^{\circ} \mathrm{E}$ to $110.00^{\circ} \mathrm{E}$ and $08.00^{\circ} \mathrm{S}$ to $10.00^{\circ} \mathrm{S}$. During west monsoon, catch of bigeye tuna was 310.39 ton, and it was caught in 350 fishing ground points. Moreover, during east monsoon tuna was caught in 117 fishing ground points. The farthest fishing ground was in the coordinate of $109.50^{\circ} \mathrm{E}$ and $12.08^{\circ} \mathrm{S}$, and around 269.17 nautical mile from Cilacap fishing port, while the nearest was in the coordinate of $108.67^{\circ} \mathrm{E}$ and $08.05^{\circ} \mathrm{S}$, and around 16.20 nautical mile.

\section{Ocean Variability Vs Catch Effort}

Ocean variability will affect to the distribution of tuna fish. The trend of SST, Chl-a and SSHA monthly describes in Figure 4.

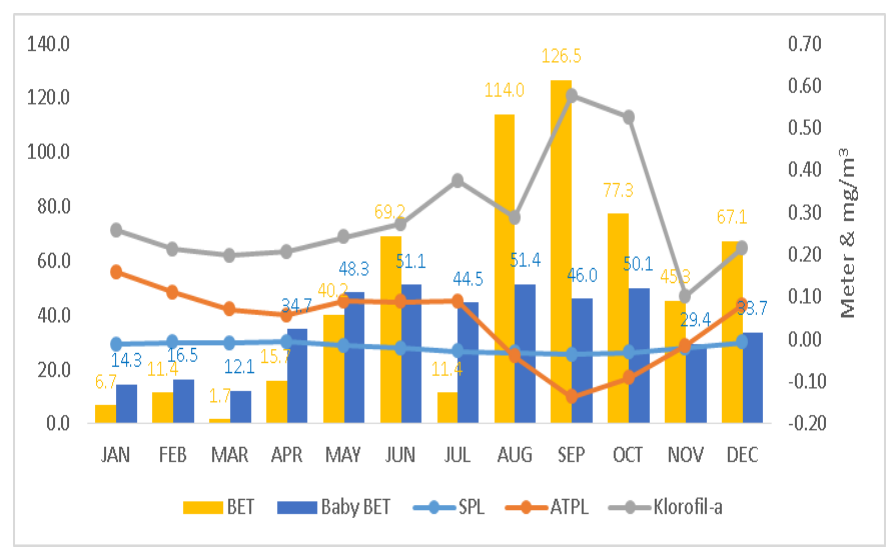

Fig. 4. Ocean variability trend vs tuna catch

The highest catch of tuna was in September (126.5 ton), where the average of SST was $25^{\circ} \mathrm{C}$, Chl-a was $0.71 \mathrm{mg} / \mathrm{m} 3$, and SSHA was $-0.14 \mathrm{~m}$. The result of correlation analysis between ocean variability and tuna catch described that all oceanographic parameters affected to tuna catch. SST and SSHA gave a negative effect to tuna catch, while Chl-a gave a positive effect. The correlation of ocean variability to tuna catch illustrated correlation value for SST was -0.719 , Chl-a was 0.717 , and SSHA was -0.791 (Table 4). When the value of SST and SSHA decreased, upwelling will occur. In this event the surface of atmosphere decreased. During upwelling, primary productivity increased, followed by the increasing of Chl-a. The highest catch of tuna commonly occurred when the Chl-a concentration increased (K. Kunarso, 2008).

TABLE IV. CORRELATION VALUE OF OCEAN PARAMETERS VS TUNA CATCH

\begin{tabular}{|l|l|r|r|r|}
\hline & & \multicolumn{1}{c|}{ SST } & \multicolumn{1}{c|}{ CHL-A } & \multicolumn{1}{c|}{ SSHA } \\
\hline \multirow{2}{*}{ BET } & CORRELATION & $-.719^{* *}$ & $.717^{* *}$ & $-.791^{* *}$ \\
\cline { 2 - 5 } & SIG. & .008 & .009 & .002 \\
\hline \multirow{2}{*}{ BABY BET } & CORRELATION & $-.711^{* *}$ & .568 & -.513 \\
\cline { 2 - 5 } & SIG. & .009 & .054 & .088 \\
\hline
\end{tabular}

Source: Statistic analysis of ocean color data, 2015

** Correlation is significant at the 0.01 level (2-tailed)

BET : Big Eye Tuna

BABY BET : Baby Big Eye Tuna

SST : Sea Surface Temperature /

CHL-A : Chlorophyll-a

SSHA : Sea Surface Height Anomaly

Accuracy calculation was applied to examine the relationship between potential tuna fishing ground that analyze using oceanographic parameters with the existing tuna fishing ground by local fishermen. The calculation applied the collected fishing ground data during 2015 (Figure 5).
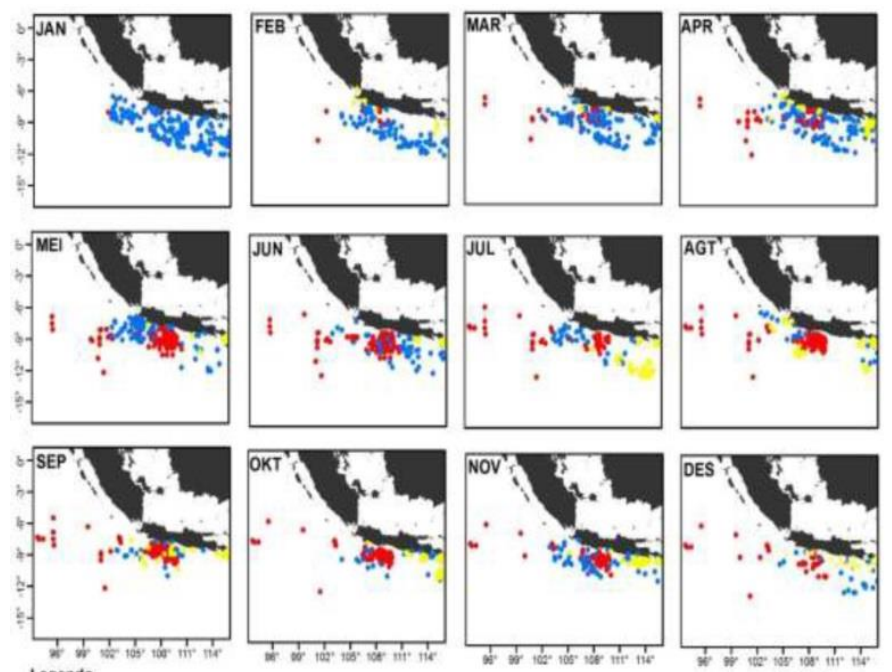

Legenda

- Fishing ground point of local fishermen

Fishing ground prediction (result of analysis)

- Potential tuna fishing ground (result of analysis

Fig. 5. Overleid map of existing tuna fishing ground and potential tuna fishing ground (Source: fishing trip and ocean color data analysis, 2015)

The overall accuracy was $78.82 \%$ (Table 5). This indicated that $78.82 \%$ of existing tuna fishing ground by local fishermen fixed with the potential tuna fishing ground resulted from the analysis of oceanographic parameters. Producer accuracy as shown in Table 5 illustrated the percentage of correct fishing ground point between existing tuna fishing ground and potential tuna fishing ground, while error omission described the percentage of error classification between existing tuna fishing ground and potential tuna fishing ground. 
TABLE V. ACCURACY ASSESSMENT OF TUNA FISHING GROUND

\begin{tabular}{|l|r|r|r|r|r|}
\hline & $\begin{array}{c}\text { FG } \\
\text { TOTAL } \\
\text { POINT }\end{array}$ & $\begin{array}{r}\text { PRODUCER } \\
\text { ACCURACY }\end{array}$ & $\begin{array}{c}\text { ERROR } \\
\text { OMISSION }\end{array}$ & $\begin{array}{c}\text { USER } \\
\text { ACCURACY }\end{array}$ & $\begin{array}{c}\text { ERROR } \\
\text { COMMISSION }\end{array}$ \\
\hline JAN & 26 & $53.85 \%$ & $46.15 \%$ & $53.85 \%$ & $46.15 \%$ \\
\hline FEB & 20 & $65 \%$ & $35 \%$ & $65 \%$ & $35 \%$ \\
\hline MAR & 28 & $67.86 \%$ & $32.14 \%$ & $67.86 \%$ & $32.14 \%$ \\
\hline APR & 24 & $95.83 \%$ & $4.17 \%$ & $95.83 \%$ & $4.17 \%$ \\
\hline MAY & 17 & $88.24 \%$ & $11.76 \%$ & $88.24 \%$ & $11.76 \%$ \\
\hline JUN & 14 & $100 \%$ & $0 \%$ & $100 \%$ & $0 \%$ \\
\hline JUL & 12 & $83.33 \%$ & $16.67 \%$ & $83.33 \%$ & $16.67 \%$ \\
\hline AUG & 8 & $100 \%$ & $0 \%$ & $100 \%$ & $0 \%$ \\
\hline SEP & 17 & $94.12 \%$ & $5.88 \%$ & $94.12 \%$ & $5.88 \%$ \\
\hline OCT & 8 & $87.50 \%$ & $12.5 \%$ & $87.50 \%$ & $12.50 \%$ \\
\hline NOV & 21 & $71.43 \%$ & $28.57 \%$ & $71.43 \%$ & $28.57 \%$ \\
\hline DEC & 8 & $75 \%$ & $25 \%$ & $75 \%$ & $25 \%$ \\
\hline TOT & 203 & OVERALL ACCURACY $=78.82 \%$ \\
\hline
\end{tabular}

$F G=$ Tuna fishing ground

\section{CONCLUSIONS AND SUGGESTIONS}

Spatial and temporal variability of the Indian Ocean, represented by Sea Surface Temperature/SST, Chlorophylla/Chl-a, and Sea Surface Height Anomaly/SSHA, was analyzed in relation with the habitat of tuna fish. Potential tuna habitat based on oceanography parameters can be a potential fishing ground for local fishermen in the fishing base of Cilacap fishing port. The analysis also examined the accuracy of potential tuna fishing ground with the existing tuna fishing ground in study area. Satellite data analysis and spatial analysis approach were combined. The spatial and temporal pattern of tuna fishing ground indicated typical of low value of SST and SSHA and high value of Chl-a. The result showed that the species of bigeye tuna mostly caught in the SST range of 25$30^{\circ} \mathrm{C}$, Chl-a ranged from 0.10 to $0.71 \mathrm{mg} / \mathrm{m} 3$, and $\mathrm{SSH}$ was 0.14 to 0.16 meter. The potential tuna fishing ground created from the analysis of oceanographic parameters and was published by the government described enough accuracy with the existing tuna fishing ground.

The information related to the accurate tuna fishing ground is very important for the fishermen to reduce any fishing operational cost. In future study, adding other oceanography phenomenon like ENSO and IOD related the spatial distribution of tuna fishing ground may improve the model pattern of tuna habitat.

\section{ACKNOWLEDGMENT}

The authors would like to thank Ministry of Research, Technology, and Higher Education, Republic of Indonesia for the research grant. We also thank to ocean color homepage for providing Sea Surface Temperature and Chlorophyll-a dataset and Marine Copernicus for Sea Surface Height data. The authors also thank to Cilacap Fishing Port for providing fisheries data and local fishermen for collecting tuna fishing ground coordinate.

\section{REFERENCES}

[1] C. Wilson and D. Adamec, Correlations Between Surface Chlorophyll and Sea Surface Height in The Tropical Pacific During The 1997/1999 El Niño-Southern Oscillation Event, J. Geophys. Res.,106,31,17531,188, 2001

[2] D. Pramudyo, I Wayan N., and S. Fadli, Karakteristik Oseanografi Fisik di Perairan Samudera Hindia Timur saat Fenomena Indian Ocean Dipole (IOD) Fase Positif tahun 1994/1995, 1997/1998, dan 2006/2007,. Jurnal Ilmu dan Teknologi Kelautan Tropis vol 3 (2) : 7184,2011

[3] G.A. Latumeten, F. Purwanti, and A. Hartoko, Analisis Hubungan Suhu Permukaan Laut, Klorofil-A Data Satelit Modis Dan Sub-Surface Temperature Data Argo Float Terhadap Hasil Tangkapan Tuna Di Samudera Hindia. Manag, Aquat. Resour, J. 2, 1-8, 2013.

[4] J. Lumban-Gao, R.R Leben, S. Vignudelli, K. Mahapatra, Y. Okada, B. Nababan, M. Mei-Ling, K. Amri, R.E. Arhatin, and M. Syahdan, Variability Of Satellite-Derived Sea Surface Height Anomaly, and Its Relationship With Bigeye Tuna (Thunnus Obesus) Catch in The Eastern Indian Ocean, European Journal of Remote Sensing, Vol. 48. Page 465477, 2015.

[5] J. W. Nybakken, Marine Biology: An Ecological Approach, 4th ed., 481 pp., Addison-Wesley, Boston, Mass. 1997.

[6] K. Kunarso, A. Supangat, W. Wiweka, Keunggulan Aplikasi Peramalan Fishing Ground Tuna di Lokasi Upwelling dengan Bantuan Citra Satelit Harian, Ilmu Kelautan 13, 127-132, 2008.

[7] Lee, Pei-Fen, I.-Ching Chen, and Wann-Nian Tzeng, Spatial and Temporal Distribution Patterns of Bigeye Tuna (Thunnus obesus) in the Indian Ocean. Zoological Studies-Taipei 44 (2): 260, 2005.

[8] L. Song and Y. Zhou, Developing an Integrated Habitat Index for Bigeye Tuna (Thunnus Obesus) in the Indian Ocean Based on Longline Fisheries Data, Fisheries Research 105 (2): 63-74, 2010.

[9] M.L. Syamsuddin, S. Sei-Ichi, H. Toru, B. Samsul, dan B.H. Agung, Effects of El Niño-Southern Oscillation Events on Catches of Bigeye Tuna (Thunnus obesus) in the Eastern Indian Ocean off Java, Fishery Bulletin 111 (2): 175-88, 2013.

[10] M. N. Habibi and T. A. Nuraini, Karakteristik dan Tren Perubahan Suhu Permukaan Laut di Indonesia Periode 1982-2009, J. Met \& Geo., Vol. 15 No. 1, hal. 37-49, 2014.

[11] M. Purba, Evidence of Upwelling and Its generation Stage Off Southern West Java During Southeast Monsoon, Bul. ITK Maritek, 5 (1) : p 21 39, 1992.

[12] O.K. Sumadhiharga, Ikan Tuna. Pusat Penelitian Oseanografi.Lembaga Ilmu Pengatahuan Indonsia, Hal 1-34, 2009.

[13] P. D. Jones, M. New, D. E. Parker, S. Martin, and I. G. Rigor, Surface Air Temperature And Its Changes Over The Past 150 Years, Reviews of Geophysics, 37, pages 1 73-199, 2 May 1999.

[14] P. Kemili, and M. R. Putri, Pengaruh Durasi Dan Intensitas Upwelling Berdasarkan Anomali Suhu Permukaan Laut Terhadap Variabilitas Produktivitas Primer Di Perairan Indonesia, Jurnal Ilmu dan Teknologi Kelautan Tropis, Vol. 4, No. 1, Hal. 66-79, Juni 2012.

[15] R. Dwi Susanto, Arnold L. Gordon, and Quanan Zheng. Upwelling along the coasts of Java and Sumatra and its relation to ENSO. Geophysical research letters, Vol. 28 No. 8 Pages 1599-1602, April 15, 2001.

[16] S.I. Sachoemar and T.Yanagi, Seasonal Variability in Sea Surface Temperature Around Java Derived From NOAA AVHRR. La mer 38 : 65-75, 2000.

[17] S. Nurdin, M. A. Mustapha, and T. Lihan, The Relationship Between Sea Surface Temperature and Chlorophyll-A Concentration in Fisheries Aggregation Area in The Archipelagic Waters of Spermonde Using Satellite Images. AIP Conf. Proc. 1571, page 466-472. 2013

[18] S. Riswanto, Status Perikanan Tuna Mata Besar (Thunnus obesus, Lowe1839) di Perairan Samudera Hindia, Selatan Pelabuhan Ratu, Sukabumi, Universitas Indonesia, 2012. 